sackie or related virus infections other seasonal factors or combinations of factors must be responsible, and these may be viral, non-viral, or both. In this case the role of Coxsackie virus would appear to be that of an initiating factor, producing subclinical islet cell damage in patients in whom diabetes is subsequently precipitated by other seasonal factors. The results of our antibody studies throw little light on this problem as neither the present study nor our previous results indicate when Coxsackie virus infection occurred in relation to the onset of diabetes.

If viruses do induce diabetes in man, the question arises as to what proportion of the total incidence of diabetes is associated with Coxsackie virus infection. There are at present few indications that maturity-onset diabetes is associated with viral infection, but in our previous investigations (Gamble et al., 1969) we found higher Coxsackie B4 virus antibody titres in non-insulin-dependent diabetics of acute onset than in controls. The numbers were too small for a significant difference to be found but the difference was of the same order as that found in the insulin-dependent diabetics and this type of patient merits further study. Of insulin-dependent diabetes, our results suggest that a substantial proportion may be associated with Coxsackie B virus infection and, if this is so, a search for a viral aetiology in the remainder would clearly be indicated. The numbers studied to date have been too small to show whether other members of the Coxsackie B groups are implicated but it is unlikely that they could account for many cases without it being apparent from our results. Other picornaviruses are obvious candidates, particularly in cases occurring in autumn, in whom we found no excess of Coxsackie virus antibodies. Mumps virus is not, however, a member of the picorna group and the possibility that other groups of virus may be involved should not be overlooked, particularly in younger children.

We gratefully acknowledge the help we have received from the many physicians who have provided information and specimens from their patients for this study. Our thanks are also due to the British Diabetic Association for grants to D.R.G. and K.W.T. which enabled this work to be carried out.

\section{References}

Adams, S. F. (1926). Archives of Internal Medicine, 37, 861.

Barboni, E., and Manocchio, K. (1962). Archivo Veterinario Italiano, 13, 447. Burch, G. E., Tsui, C.-Y., Harb, J. M., and Colcolough, H. L. (1971). Archives of Internal Medicine, 128, 40.

Coleman, T. J., Gamble, D. R., and Taylor, K. W. (1973). British Medical Fournal, 3, 25.

Craighead, E., and McLane, M. F. (1968). Science, 162, 913.

Gamble, D. R., Kinsley, M. L., Fitzgerald, M. G., Bolton, R., and Taylor, K. W. (1969). British Medical fournal, 3, 627.

Gamble, D. R., and Taylor, K. W. (1969). British Medical fournal, 3, 631.

Harrison, A. K., Baller, S. P., and Murphy, F. A. (1972). Experimental and Molecular Pathology, 17, 206.

Nerup, J., Anderson, O. O., Bendixen, G., Egeberg, J., and Poulsen, J. E. (1971). Diabetes, 20, 424.

Newton, W. A., cited by Craighead, J. E. (1972). In Handbook of Physiology, ed. D. F. Steiner and N. Freinkel, vol. 1, p. 319. Washington D.C., American Physiological Society.

\title{
Alteration of Bile Salt Metabolism by Dietary Fibre (Bran)
}

\author{
E. W. POMARE, K. W. HEATON
}

British Medical fournal, 1973, 4, 262-264

\section{Summary}

Feeding dietary fibre in the form of bran induced changes in bile salt metabolism in five people with intact gall bladders. There was evidence of reduced dehydroxylation of bile salts; the proportion of deoxycholate conjugates in bile was reduced and the transfer of radioactivity from labelled taurocholate to deoxycholate was decreased. These findings, which were independent of changes in intestinal transit rate, imply that bran reduced the degradation of bile salts by colonic bacteria. This property of bran accords with recent theories that fibre-depleted diets favour the degradation of bile salts in the colon. These findings may be relevant to the aetiology of large bowel cancer.

\section{Introduction}

There is increasing interest in the possibility that fibredepleted foods (especially white flour and sugar) are concerned in the causation of various diseases of modern civilization (Cleave et al., 1969; Burkitt, 1971, 1973; Heaton, 1973 a). With two of these diseases, carcinoma of the colon and gall stones, it has been suggested that degradation of bile salts by

\footnotetext{
University Department of Medicine, Bristol Royal Infirmary, Bristol BS2 8HW

E. W. POMARE, M.R.A.C.P., Research Fellow

K. W. HEATON, M.D., M.R.c.P., Consultant Senior Lecturer in Medicine
}

colonic bacteria may play a pathogenetic part (Burkitt, 1971; Hill et al., 1971; Heaton, 1972). Burkitt (1971) claimed that degradation of bile salts is favoured by a low-residue, fibredepleted diet. Evidence is, however, lacking for this speculation.

Bran is the fibre-rich fraction of wheat which is discarded in the milling of white flour. It is known to influence the motility of the intestine (Cummings, 1973; Harvey et al., 1973), while diets rich in mixed cereal and vegetable fibre cause increased faecal excretion of calories, fat, and nitrogen (Southgate and Durnin, 1970). In vitro, fibre has bile salt binding properties (Eastwood and Hamilton, 1968). Nevertheless, the effects of fibre on bile salt metabolism have not been reponted except for conflicting statements that faecal bile acid excretion is or is not increased by a raised intake of cellulose (Shurpalekar et al., 1971; Stanley et al., 1972; Eastwood et al., 1973), bran (Eastwood et al., 1973), or mixed fibre (Antonis and Bersohn, 1962). We have studied the effect of bran on bile salt metabolism using radioactively labelled bile salts and analysing duodenal bile.

\section{Subjects and Methods}

The subjects studied were three healthy women with normal cholecystograms, two women with symptomless gall stones in functioning gall bladders, and six women who had undergone cholecystectomy but were otherwise in good health. All were volunteers who had given informed consent. All 11 subjects were given a tracer dose of 3 to $5 \mu \mathrm{Ci}$ radioactive bile salt intravenously, and on each of the next four mornings bile was aspirated from the duodenum. Subjects with intact gall bladders were given cholecystokinin to stimulate 
bile flow. Five of the cholecystetomy subjects received deoxycholic acid-24-1t $\mathrm{C}$, while all the others were given sodium taurocholate- $24-{ }^{11} \mathrm{C}$, these materials being of at least $99 \%$ radiochemical purity. Bile samples were extracted with alcohol and subjected to thin layer chromatography to separate the main conjugated bile salt fractions. These were then eluted and the following measurements made (Low-Beer et al., 1973; Pomare and Heaton, 1973): (1) the relative proportions of the three main bile salts, cholate, chenodeoxycholate, and deoxycholate; (2) in subjects given labelled taurocholate, the percentage of bile radioactivity in metabolites of taurocholate-namely, glycocholate, glycodeoxycholate and taurodeoxycholate; and (3) specific activity of the originally labelled bile salt fraction. In subjects given labelled deoxycholic acid, the half life, pool size, and daily production of deoxycholate were calculated from the specific activity decay curve and the administered dose of radioactivity. Unfortunately, these calculations could not be made from the radioactive taurocholate studies because during bran feeding taurocholate was deconjugated so rapidly that its specific activity decay curve was non-linear.

All subjects underwent a control study and then added unprocessed bran to their normal diets $(33 \pm 10 \mathrm{~g} /$ day in divided doses with meals, except for one subject who took $100 \mathrm{~g}$ ) for six to 10 weeks under close supervision. All the above measurements were then repeated while they continued to take bran.

Statistical significance of differences were tested by Student's paired $t$ test and the Wilcoxon-White rank sum test.

\section{Results}

Subjects with and without gall bladders are considered separately because while this study was in progress a parallel investigation indicated that loss of the gall bladder results in increased bacterial degradation of bile salts (Pomare and Heaton, 1973).

\section{SUBJECTS WITH GALL BLADDERS}

The composition of the bile salt pool was markedly altered by bran (fig. 1). The proportion of deoxycholate was halved, falling from $27 \cdot 1 \pm 8.9 \%$ (mean \pm 1 S.D.) to $13 \cdot 8$ $\pm .4 \%(P<0.025)$. This was matched by an increase in the proportion of chenodeoxycholate from $30.6 \pm 3.6 \%$ to 43.9 $\pm 2.7 \%(\mathrm{P}<0.005)$. The proportion of cholate remained unchanged at $42 \cdot 2 \%$.

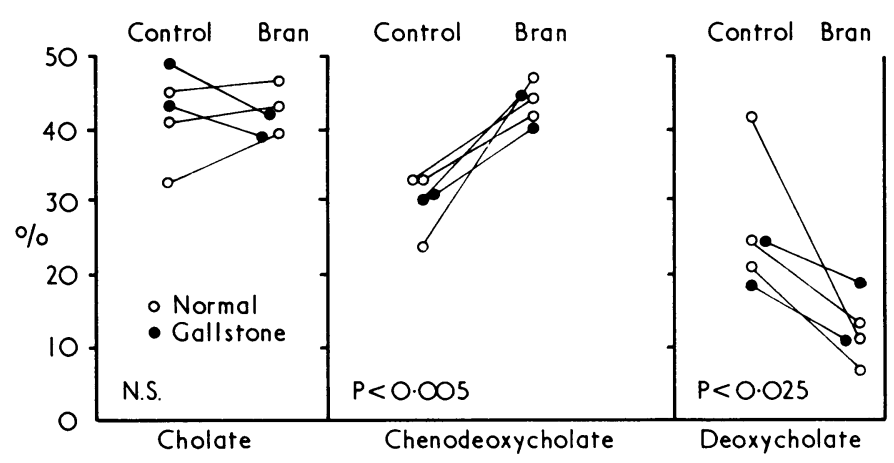

FIG 1-Effect of bran on composition of bile salt pool expressed as percentages of its three main components, cholate, chenodeoxycholate, and deoxycholate. Results before and during administration of bran. N.S. = Not significant.
The transfer of taurocholate radioactivity to its circulating metabolites was altered by bran in two separate ways. Firstly, there was evidence of increased deconjugation. In the bile sample taken 24 hours after the administration of labelled taurocholate, the radioactivity present in reconjugated form (that is in glycocholate, glycodeoxycholate, and taurodeoxycholate) increased from $32.6 \pm 18.1 \%$ in the control study to $54.7 \pm 17.2 \%$ with bran $(\mathrm{P}<0.01)$. This difference was less apparent on the second day $(P<0.025)$ and disappeared by the third day. Secondly, the proportion of each day's bile radioactivity in the combined glycodeoxycholate and taurodeoxycholate fractions was consistently lower during bran feeding (fig. 2). On average, the proportion fell from 8.2 to $5.1 \%$ on day 1 ; from 19.5 to $8.2 \%$ on day 2 ; from 27.1 to $11.2 \%$ on day 3 ; and from 36.8 to $14.8 \%$ on day 4 (P 0.02 on days 1,2 , and $4, \mathrm{P} 0.05$ on day 3 ). These data suggest that the reduced proportion of deoxycholate in the bile during bran feeding was due to less deoxycholate being returned to the liver.

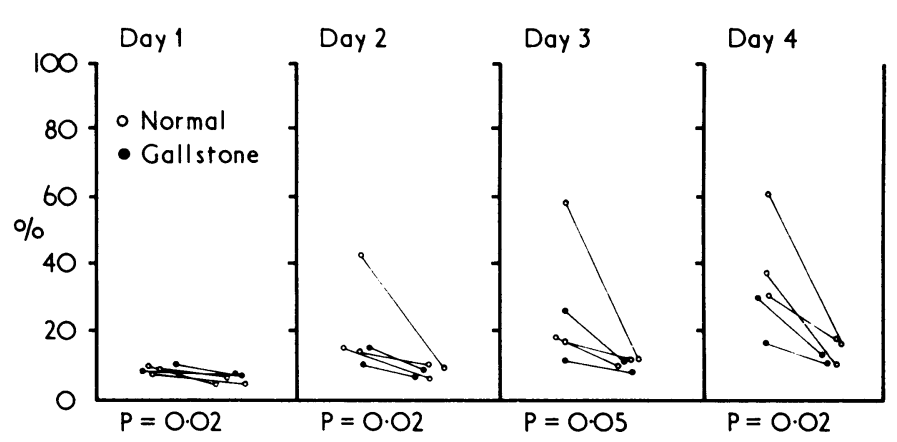

FIG 2-Percentage of bile radioactivity present in deoxycholate conjugates on each of four days after administration of sodium taurocholate-24-14 C. Results before and during administration of bran.

\section{CHOLECYSTECTOMY SUBJECTS}

These subjects started with a high proportion of deoxycholate and a low proportion of chenodeoxycholate in their bile, as previously reported (Pomare and Heaton, 1973), and in them bran feeding made no significant difference to the composition of the bile salt pool (see table I). In the one subject studied after administration of labelled taurocholate, bran failed to reduce the transfer of radioactivity to deoxycholate.

TABLE I-Percentage Composition of Bile Salt Pool in Six Cholecystectomy Subjects before and during Bran Feeding (Mean \pm 1 S.D.)

\begin{tabular}{|c|c|c|c|c|}
\hline & & Cholate & Chenodeoxycholate & Deoxycholate \\
\hline $\begin{array}{l}\text { Control } \\
\text { With hran }\end{array}$ & $\begin{array}{l}\cdots \\
\cdots\end{array}$ & $\begin{array}{l}30 \cdot 1 \pm 6 \cdot 3 \\
32 \cdot 7 \pm 2 \cdot 7^{*}\end{array}$ & $\begin{array}{l}31 \cdot 1 \pm 13 \cdot 8 \\
33 \cdot 0 \pm 11 \cdot 0^{*}\end{array}$ & $\begin{array}{l}38 \cdot 8 \pm 14 \cdot 3 \\
34 \cdot 2 \pm 11 \cdot 4^{*}\end{array}$ \\
\hline
\end{tabular}

* Not significantly different from control.

Bran feeding made no significant difference to the pool size, daily production, or half life of deoxycholate in five cholecystectomy subjects (table II).

TABLE II-Kinetic Data Obtained from Deoxycholate-24- ${ }^{14} \mathrm{C}$ Studies in Five Cholecystectomy Subjects before and during Bran Feeding (Mean \pm 1 S.D.)

\begin{tabular}{|c|c|c|c|c|}
\hline & & $\begin{array}{c}\text { Half Life } \\
\text { (days) }\end{array}$ & $\begin{array}{l}\text { Daily Production } \\
\text { (mg!day) }\end{array}$ & $\begin{array}{c}\text { Pool Size } \\
(\mathrm{g})\end{array}$ \\
\hline $\begin{array}{l}\text { Control ... } \\
\text { With hran }\end{array}$ & $\begin{array}{l}\cdots \\
\cdots\end{array}$ & $\begin{array}{l}2 \cdot 18+0.29 \\
2.01 \pm 0.14^{*}\end{array}$ & $\begin{array}{l}126 \pm 56 \\
133 \pm 48^{*}\end{array}$ & $\begin{array}{l}0.47 \pm 0.21 \\
0.45 \pm 0.21 *\end{array}$ \\
\hline
\end{tabular}

* Not significantly different from control. 


\section{Discussion}

We have shown that adding fibre to the diet in the form of unprocessed bran alters the bacterial metabolism of bile salts. In particular, it reduces the amount of dehydroxylated bile salt-that is, deoxycholate-appearing in the bile (at least in subjects with a gall bladder). This implies either that less deoxycholate is formed or that less is absorbed. Reduced absorption is unlikely because the half life of radioactive deoxycholate was not shortened. Further, in Afro-Asian communities, where a high fibre diet is eaten, the faeces contain less, not more, deoxycholate than in Western society (Hill et al., 1971). The data suggest, therefore, that dietary fibre reduces the formation of deoxycholate.

Deoxycholate is formed in the colon when bacteria remove the $7 \alpha$-hydroxyl group of cholate. Cholate is one of the two major bile salts synthesized by the liver, the other being chenodeoxycholate. Chenodeoxvcholate is also $7 \alpha$-dehydroxylated by colonic bacteria, with the formation of lithocholate (Midtvedt and Norman, 1968). Lithocholate could not be measured by the techniques of the present study. Nevertheless, bran probably reduces the produotion rate of lithocholate as well as of deoxycholate. Against this, however, must be placed the relative increase in the precursor of lithocholate, chenodeoxycholate.

Deoxvcholate and lithocholate have both been shown to have pathogenic properties in animals. Over 30 years ago deoxycholate was shown to have carcinogenic properties when injected into rats (Badger et al., 1940; Cook et al., 1940), while Hill et al. (1971) have drawn attention to the close correlation between the geographical incidence of large bowel cancer and the faecal concentration of deoxycholate. Animal experiments show that lithocholate can inhibit the svnthesis of cholate and also the secretion of bile (Heaton, 1972) and it has been proposed that the secretion of gall stone-forming bile might be favoured by excessive formation and absorption of lithocholate (Heaton, 1973 b). Epidemiologically, both colonic cancer and gall stones are associated with the consumntion of low-residue, fibre-depleted diets (Burkitt, 1971; Heaton, 1973 a). The present findings support the concept that fibre-depleted diets may be pathogenic by allowing extensive bacterial degradation of the bile salt nucleus.

The "dose" of bran used in this study was physiological. Thirty-three grammes of bran is equivalent to about $165 \mathrm{~g}$ of wholemeal flour. In 1970 the amount of flour available in this country was $181 \mathrm{~g} /$ person/day (C. T. Greenwood, personal communication, 1973).

Bran reduces dehydroxylation by several possible mechanisms. These are an alteration in the bacterial flora of the colon with fewer bacteria able to dehydroxylate bile salts, a change in the physical chemistry of the colonic lumen with inhibition of the enzvme $7 \alpha$-dehvdroxylase, and reduced bile salt/bacterium contact due to bulkier, more dilute colonic cointents or to faster transit. Faster colonic transit may in fact be discounted: in two out of five subjects bran did accelerate transit, but in three an initially rapid transit was slowed by bran (as alreadv reported, Harvey et al. 1973). Alteration in the bacterial flora or in its enzvmic activity cannot be ruled out, but is rendered less likely bv the ineffectiveness of bran in cholecystectomy subjects. Bran may well prevent physical contact between bile salts and colonic bacteria, since dietary fibre increases both the solid matter and the water in the faeces (Cummings, 1973).

The failure of bran to reduce bile deoxycholate in cholecystectomy subjects is probably explained by the fact that removal of the gall bladder compels bile salts to circulate and meet colonic bacteria constantly, even during fasting, when there is no chance of contact between bile salts and bran. The lack of effect of bran on deoxycholate half life in cholecystectomy subjects may, however, be taken as evidence that bran does not sequester bile salts since, experimentally, a bile salt-sequestrating agent, cholestyramine, is just as effective in rats which lack a gall bladder as in hamsters which have one (Cook et al., 1971).

While decreasing the proportion of deoxvcholate in bile, bran increased that of chenodeoxycholate. This may be explained by the recent discovery that deoxycholate selectively inhibits the synthesis of chenodeoxvcholate (Low-Beer et al., 1972; Low-Beer and Pomare, 1973). Bran also promoted the deconjugation of taurocholate. In the economy of bile salts, deconjugation probably has little importance. (Fromm and Hofmann, 1971; Hepner et al., 1972). Normally it occurs within both the ileum and colon (Heaton, 1972). Increased deconjugation occurs in the stagnant loop syndrome (Tabaqchali and Booth, 1970) where, however, there is also increased dehydroxylation (Mallory et al., 1973). Deconjugation with a tendency to reduced dehydroxylation has been noted after ileostomy (Morris et al., 1973). The mechanism by which bran promotes deconjugation while inhibiting dehydroxylation remains to be worked out.

We wish to thank Dr. T. S. Low-Beer for helpful discussions, and Professor A. E. Read for his support in this research.

\section{References}

Antonis, A., and Bersohn, I. (1962). American fournal of Clinical Nutrition, 11,142 .

Badger, G. M., et al. (1940). Proceedings of the Royal Society, B, 129, 439. Burkitt, D. P. (1971). Cancer, 28, 3.

Burkitt, D. P. (1973). British Medical fournal, 1, 274

Cleave, T. I.., Campbell, G. D., and Painter, N. S. (1969). Diabetes, Coronary Thrombosis and the Saccharine Disease, 2nd edn., Bristol, Wright.

Cook, D. A., Hagerman, L. M., and Scheider, D. L. (1971). Proceedings of the Societv for Experimental Biology and Medicine, 138, 830

Cook, J. W., Kennaway, E. L., and Kennaway, N. M. (1940). Nature, 145,

Cummings, J. H. (1973). Gut, 14, 69

Eastwood, M. A., and Hamilton, D. (1968). Biochimica Biophysica Acta,

$152,165$.
Eastwood, M. A., Hamilton, T., Kirkpatrick, J. R., and Mitchell, W. D. (1973). Proceedings of the Nutrition Society, 32, 22A.

Fromm, H., and Hofmann, A. F. (1971). Lancet, 2, 621.

Harvey, R. F., Pomare, E. W., and Heaton, K. W. (1973). Lancet, 1, 1278.

Heaton, K. W. (1972). Bile Salts in Health and Disease. Edinburgh, Churchil Livingstone.

Heaton, K. W. (1973 a). Clinics in Gastroenterology, 2, 67.

Heaton, K. W. (1973 b). In Ninth Advanced Symposium on Advanced Medicine, ed. G. Walker, p. 363. London, Pitman

Hepner, G. W., Hofmann, A. F., and Thomas, P. J. (1972). Fournal of Clinical Investigation, 51, 1889.

Hill, M. J., et al. (1971). Lancet, 1, 95.

Low-Beer, T. S., Heaton, K. W., Pomare, E. W., and Read, A. E. (1973). -But, 14, 204 .

Low-Beer, T. S., and Pomare, E. W. (1973). Gastroenterology, 64, 764.

Low-Beer, T. S., Pomare, E. W., and Morris, J. S. (1972). Nature New Biology, 238, 215

Mallory, A., Kern, F., Smith, J., and Savage, D. (1973). Gastroenterology, 64, 26.

Midtvedt, T., and Norman, A. (1968). Acta Pathologica Microbiologica Scandinavica, $72,313$.

Morris, J. S., Low-Beer, T. S., and Heaton, K. W. (1973). Scandinavian Fournal of Gastroenterologv, 8, 425

Pomare, E. W., and Heaton, K. W. (1973). Gut, 14, 753.

Shurpalekar, K. S., Doraiswamy, T. R., Sundaravalli, O. E., and Narayana Rao, M. (1971). Nature, 232, 554.

Southgate, D. A. T., and Durnin, J. V. G. A. (1970). British fournal of Nutrition, 24, 517 .

Stanley, M., Paul, D., Gacke, D., and Murphy, J. (1972). Gastroenterology, $62,816$.

Tabaqchali, S., and Booth, C. C. (1970). In Modern Trends in Gastroenterology, 4, ed. W. I. Card and B. Creamer, p. 143. London, Butterworths. 